\title{
Innovative Pavement Materials and Design: Smart Roadways and Smart Road Maintenance for the Future
}

\author{
Sherif Hashem \\ sherif.hashem@ceg-qatar.com \\ CEG International, Doha, Qatar \\ Clinton Cardiño \\ clinton.cardino@ceg-qatar.com \\ CEG International, Doha, Qatar
}

\begin{abstract}
In an ever-changing world, innovation presents itself as the lifeblood that can make or break any industry or economy. The transportation construction sector is no exception, however, innovation and doing things differently in this sector has been dead slow for centuries, compared to other industries. Automobiles have developed significantly over the years, but the way we build, roadways has not. Innovative vehicles should entail innovative roads to be able to cater them. This paper looks into this subject from a practical perspective with some degree of theoretical depth. It provides a high-level review of a range of cutting technological innovations that can be readily adopted and applied in the State of Qatar and the region in the future. This includes innovative ideas such as solar roadways, plastic roadways, and app-aided road maintenance ignited through the use of the powerful design-build project delivery approach, in addition to addressing the strategic need for building a vivid innovation-driven organizational work culture. The paper is influenced by the author's iconic book 'The Power of DesignBuild', USA, (Hashem, 2014), and a number of research and innovation articles and papers in the transportation and infrastructure sector around the world. Daring to adopt innovation and new ideas is a must to advance the roadway construction sector and catch up with the needs and ambitions of the 21 st century.
\end{abstract}

Keywords: Innovation; Design-build; Asphalt; Solar roadways; Plastic roadways; Mobile apps

\section{INTRODUCTION}

Innovation in pavement design and construction is following the typical axiomatic timeline of innovation of things extending from the far past to the far future, as shown in Figure 1.

\section{TODAY}

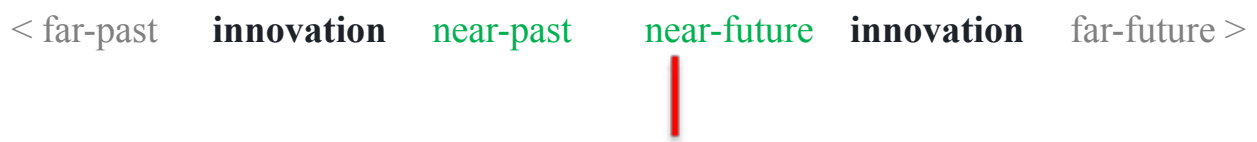

Figure 1: The axiomatic innovation timeline 
The first asphalt roads were laid thousands of years ago, namely, in Babylon $625 \mathrm{BC}$, using primitive forms and shapes of road base and a top layer of natural bitumen for waterproofing. The first modern asphalt roads as we know them today were first built in Europe in late 1700's, then enhanced and perfected in early 1800's by the Scottish road engineer J. L. Macadam, after whom the current flexible Macadam pavement is labelled. Surprisingly, despite the exponential growth in technology since the 1800's, we are still building roads using broken stones and asphalt the way Macadam did hundreds of years ago. The only key change that occurred to asphalt pavements ever since, was in early 1900 's with the use of refined petroleum instead of natural asphalt. In the meantime, technologies of land transportation developed big time during the same time period, from horse carts and steam powered wagons in the 1700's and 1800's to nowadays $21^{\text {st }}$ century's electrically powered and automatic self-driven vehicles. Figure 2 below provides an overview of the slow pace of technological development in pavement design and construction vs the same in automobiles in recent centuries. The slow development of road pavements has contributed to limiting automobiles safety and maximum driving speeds which are governed by road alignment roughness and quality of pavement. On the other hand, with the steady increase of traffic load, numbers of vehicles and trips, asphalt roads life spans decreases to as low as three to five years before the first maintenance becomes necessary. Cost of road construction and maintenance soars high due to the heavy equipment, hefty materials, intensive labor, and long time required to build roads the old Macadam way. Apart from toll ways and roadside shops, current roadways do not generate income nor have direct ROI, making them a financial burden on governments and taxpayers. Moreover, the environmental impacts and carbon footprints of the current asphalt roads have become just intolerable. The pollution caused by the production of fossil asphalt and that caused by the countless trips of trucks required to transport and compact road construction materials and build asphalt roads is enormous. Moreover, the current asphalt roads are sensitive to road maintenance and hard to maintain. Advancing the ways of design, construction and maintenance of roadways and prolonging roadways service life have therefore become an urgent need. Several groups in the industry realized this fact in recent decades. The academia and research centers recently began to respond with various design-build innovations trying to break the cycle of technological monotony and catch up with the technological revolution going on in the world.

\begin{tabular}{|c|c|c|c|c|}
\hline 1700’s & $1800^{\prime} \mathrm{s}$ & 1900 's & 2000’s & Innovation \\
\hline 1 & $\mathbf{L}$ & $\mathbf{L}$ & $\perp$ & \\
\hline & & & & \\
\hline Pavement - Slow Deve & lopment & & 20 & 20 \\
\hline Asphalt & Asphalt & Asphalt & Asphalt & Solar Roadways \\
\hline First use in Europe & Macadam pavement & Macadam pavement & Macadam pavement & Plastic Roadways \\
\hline Natural Sources & Natural Sources & Refined Petroleum & $\begin{array}{l}\text { Refined Petroleum } \\
\text { PMB Additives }\end{array}$ & App-Aided Maintenance \\
\hline Automobiles - Steady & Development & & & \\
\hline $\begin{array}{l}\text { Steam-Powered } \\
\text { Horse Carts }\end{array}$ & $\begin{array}{l}\text { Gasoline-Powered } \\
\text { Combustion Engines }\end{array}$ & $\begin{array}{l}\text { Turbo-Powered } \\
\text { Mass Production } \\
\text { Assembly Lines }\end{array}$ & $\begin{array}{l}\text { Hybrid-Powered } \\
\text { Heavy Trucks } \\
\text { High Speed }\end{array}$ & $\begin{array}{l}\text { Plug-in Electric } \\
\text { Giant Trucks } \\
\text { Smart Cars }\end{array}$ \\
\hline
\end{tabular}

Figure 2: Pavement vs automobiles development timeline 
This paper provides a high-level review of a number of recent $21^{\text {st }}$ century emerging innovations, which attempt to change the status quo in pavement design, construction and maintenance done in the near past or for application in the near future. As always, innovation constitutes change, and change is a process that takes time, money, and relentless dedication.

\section{PAVEMENT INNOVATIONS FOR THE FUTURE}

This chapter presents three innovative concepts related to pavement design, construction, and maintenance management. All three concepts are in final stages of research and development, i.e. although they did not pass the test of time, yet, they are expected to roll out gradually and become popular in the near future. Before final adoption and mass production, innovations shall have to get into cycles of PDCA improvements until deemed and declared fit for purpose. Each concept is presented under a dedicated sub-chapter. Sub-chapters are designed to have three implicit parts into them, namely, background and what the innovation is trying to achieve, a brief system description, and the way forward. Innovations prove that the gap between dreams and reality is achievable.

\subsection{Solar roadways - The power of solar energy}

The innovative concept of solar roadways which can generate power from the sun has gained popularity in recent years as a smart alternative to the traditional asphalt roads dominating the scene around the world. The key selling point of solar roads is that they can produce clean energy, a precious commodity. The recent emergence of Plug-in Electric Vehicles (EVs) has added fuel to the idea of solar roadways as it provides the answer to the question, how can EVs be charged economically? On the other hand, the solar energy industry is growing steadily, and recently started to extend a hand to the highways industry through intensive research to support the use of solar panels as paving material. The size of the job is hundreds of millions of kilometers of roadways existing or to be built around the world. Solar roadways are still in the offing; however they appear to be here to stay. When fully developed, solar roadways will be able to generate clean electric energy from the sun that is enough to power the ITS system embedded in the pavement solar panels, street lights along the roads, the electrical automobiles driving on the pavement solar panels, and even the buildings and facilities erected along the roads, as shown in Figure 3.

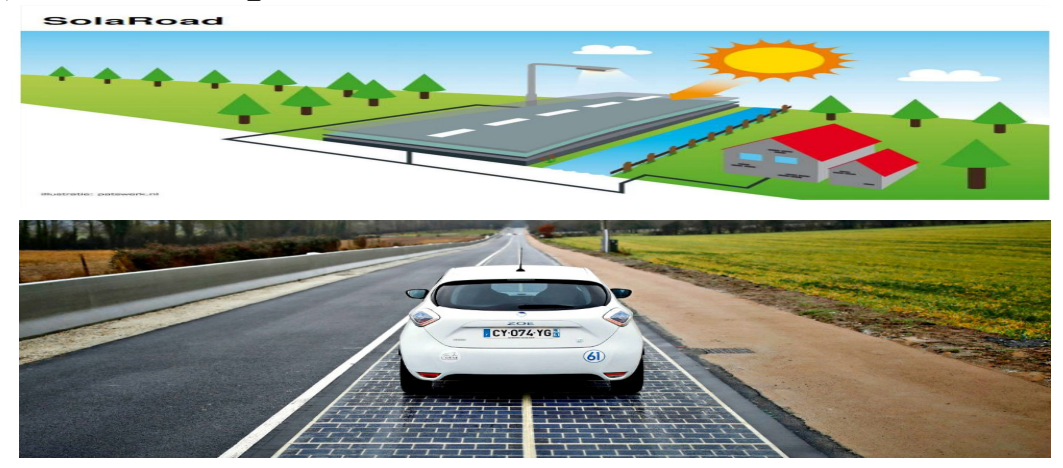

Figure 3: Solar roadways 
A pioneer in the field of using solar panels to pave roadways is the USA company Solar Roadways ${ }^{\circledR}$. The company is working on prototyping solar road pavements built out of a modular system of specially engineered solar panels that can be walked and driven upon. Solar roadways panels contain LED lights to create lines and signage without paint. The panels also have microprocessors, which makes them intelligent. This allows the panels to communicate with each other, with a central control station, and with vehicles and motorists. Solar roadways panels are made of specially formulated tempered glass, which can support traffic loads. Glass has a traction surface that is equivalent to asphalt. Solar roadways are designed to outperform asphalt in many key technical, economical, and performance aspects as shown in Table 1, (Brusaw, 2019).

Table 1: Comparison between solar and asphalt roadways

\begin{tabular}{|l|l|l|}
\hline Surface Features & Solar Roadways & $\begin{array}{l}\text { Asphalt Road- } \\
\text { way s }\end{array}$ \\
\hline Flat place to walk and drive & & \\
\hline Rough to allow traction and skid resistance & & \\
\hline Can be designed and engineered & & \\
\hline Water can be stored, treated or moved & & \\
\hline Doesn't soften at high temperatures & & \\
\hline Generates energy & & \\
\hline Intelligent Traffic System & & \\
\hline LED lights for lines and signage & & \\
\hline Remains snow/ice free & & \\
\hline Impervious to potholes & & \\
\hline Modular for faster maintenance & & \\
\hline Requires no paint & & \\
\hline Has ROI & & \\
\hline Facilitates energy independence & & \\
\hline Can charge EVs with clean energy & & \\
\hline Passed the test of time & & \\
\hline Mass production and usage experience & & \\
\hline
\end{tabular}

Solar roadways are made of photovoltaic solar panels that are able to convert sunrays into electricity by exciting electrons in silicon cells using the photons of light from the sun. Solar panels come in three main types, namely, monocrystalline, polycrystalline, or thin-film. A key factor affecting the feasibility of solar roadways is the efficiency of the solar panels paving the roads. Solar cell efficiency refers to the portion of energy in the form of sunlight that can be converted via photovoltaics into electricity by the solar cell. The efficiency of the solar cells used in a photovoltaic system, in combination with other external factors, determines the electrical energy output of the system. For instance, a solar panel of $20 \%$ efficiency and area of $1 \mathrm{~m} 2$ would produce $200 \mathrm{kWh}$ at standard test conditions. This output increases when weather is clear and the sun is high in the sky, and will decrease in cloudy conditions or when the sun is low in the sky. Therefore, the use of solar panels in the State of Qatar can be very effective and efficient given the predominantly clear and sunny skies most of the year. According to a study titled, "Assessment of Solar and Wind Energy Potential in Qatar", (Rao \& Al-Kuwari, 2013), 
the State of Qatar receives an average annual insolation of $2000 \mathrm{kWh} / \mathrm{m} 2 /$ year. That means, the same panel described above can be expected to produce $400 \mathrm{kWh}$ of energy per year. Moreover, the good news is that the solar panels technology is improving steadily over time with solar panel efficiencies of $5-20 \%$ in the 1980 's, to $30 \%$ in the 2000 's and recently $45 \%$ in 2020 and expected to improve more.

On the other hand, it should be noted that the physical condition of the solar panels forming the road pavement can significantly affect solar panels' efficiency and feasibility of solar roadways. Keeping road pavement and surface clean and intact is therefore of paramount importance. A pilot solar roadway project was launched by The Ministry of Environment in France in 2016 trying to test the system and measure the actual output of solar panels when used as road pavement under real traffic conditions; the WattWay project, (Pasley, 2019), see Figure 2. The WattWay road project was paved by ca 3000 $\mathrm{m} 2$ photovoltaic solar panels ( $3 \mathrm{~m}$ wide single lane $\mathrm{x} 1 \mathrm{~km}$ long). The projected electric energy was ca 150,000 kWh a year, enough to power 15 homes using the rates published by the US Energy Information Administration (Robert, 2018). The output energy however declined in subsequent years due to deterioration of road surface indicating the need for further study, improvement, and testing. The energy output declination could be attributed to a combination of poor quality of both road and solar panels construction.

Conclusion: Solar roadways is an innovative technology, which supports the recent rise of electric vehicles and the global pressing need for sustainability and clean energy. The innovation is still under research and development, however, it can now be applied strategically at small scale e.g. around public facilities such as FIFA 2022 stadiums or public parks, even for pedestrians only, just to show the world commitment to innovation, sustainability and clean energy.

\subsection{Plastic roadways - Fast installation and long life}

The modern problem of excessive plastic production, combined with the global concern regarding the large cost, long time, disruption to the public and pollution caused by traditional asphalt road construction and road maintenance were the reason why plastic roadways were born.

Plastic roadways is an innovative answer to the long due problems of traditional asphalt and concrete roads. Imagine constructing stretches of roads 'within days' instead of months. Visualize a long-lasting road without a need for regular road maintenance and traffic disruptions. Envision being able to preserve your assets without nuisance while ensuring sustainability and supporting the campaign for a greener environment by recycling plastic wastes.

As shown in Figure 4 below, plastic roadways consist of light, prefabricated, modular and hollow road structure made from recycled plastics with a life expectancy up to three times as long as the traditional asphalt pavement. It is prebuilt and can be easily installed on site preventing excessive disruption to the public or traffic operations. Hollow spaces within the plastic pavement can be used for cables and pressure pipes omitting the need for excavation, and furthermore serves as temporary storage for storm water preventing flooding during extreme precipitation. 


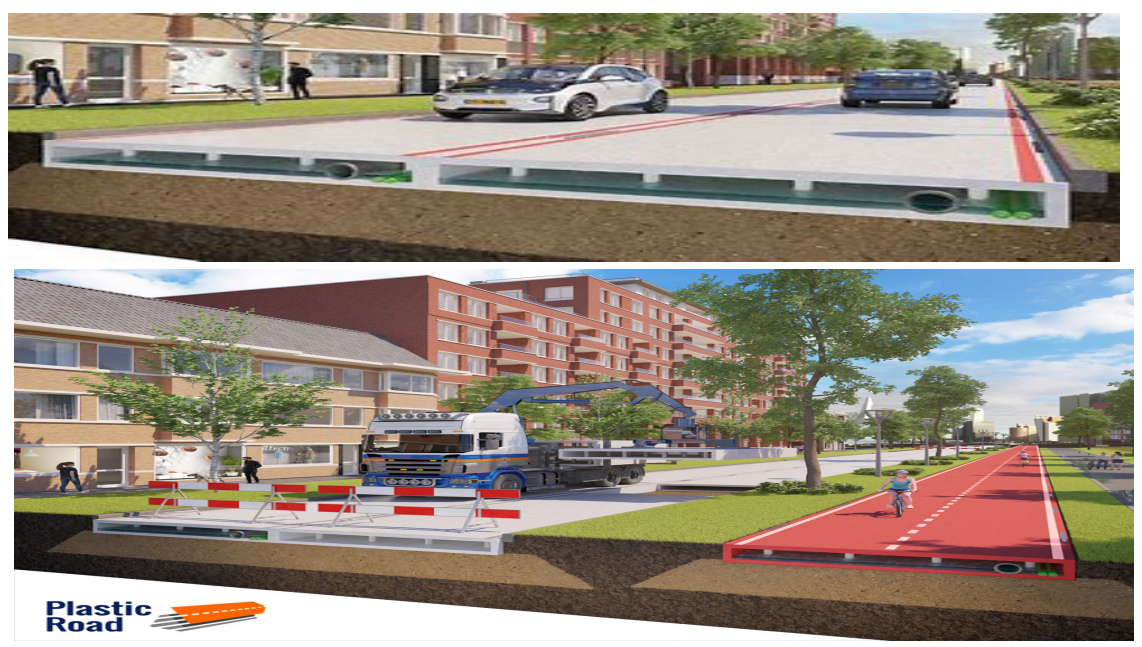

Figure 4: Plastic roadways

Plastic roadways' lightweight characteristic, being four times lighter than traditional road structure, reduces the pressure due to construction, which makes it a perfect option on locations with weak or compressible subsoil subject to settlement. The plastic material composition and structure eliminates the risk of cracks and potholes commonly experienced in asphalt pavement, thus reducing the need for road maintenance. Plastic roadways are manufactured from recycled post-consumer plastics, which contributes to solving the global problem arising out of excessive plastic production in an innovative and sustainable way, while ensuring an economically priced road.

Plastic roadways are designed to outperform asphalt roads in many key technical, economical, and road pavement performance aspects, as shown in Table 2 below.

Table 2: Comparison between plastic and asphalt roadways

\begin{tabular}{|l|l|l|}
\hline Surface Features & Plastic Roadways & Asphalt Roadways \\
\hline Flat place to walk and drive & & \\
\hline Rough to allow traction and skid resistance & & \\
\hline Can be designed and engineered & & \\
\hline Water can be stored, treated or moved & & \\
\hline Doesn't soften at high temperatures & & \\
\hline Impervious to potholes & & \\
\hline Modular for faster installation & & \\
\hline Modular for faster maintenance & & \\
\hline Long life span - up to three times & & \\
\hline Sustainable - made of recycled material & & \\
\hline Light weight & & \\
\hline Passed the test of time & & \\
\hline Mass production and usage experience & & \\
\hline
\end{tabular}


The Plastic Roadways concept was launched in 2015 by KWS, a Dutch road construction company. In 2016, KWS collaborated with Wavin and Total, all subsidiaries of the Dutch group VolkerWessels, for further development of the concept. On September 112018 , the world's first plastic road pilot project opened in the municipality of Zwolle in the Netherlands. It was a 30-meter long bicycle path made of recycled plastic, equivalent to more than 218,000 plastic cups. The $30 \mathrm{~m}$ stretch was laid in just few hours. On November 22nd 2018 a second pilot project of a similar size was launched. The second pilot project took place in the municipality of Giethoorn, which is also in the Netherlands, taking advantage of the lessons learned in Zwolle. The construction team used lighter equipment during construction, and drove it directly over the placed plastic road elements instead of next to them. Both pilot projects in Zwolle and Giethoorn are being continuously monitored for five years. In the meantime, both pilot projects are regularly evaluated in order to further develop the concept into a product that can be introduced to the market (PlasticRoad, 2019).

Conclusion: Plastic roadways is a promising concept that's aligned with the pressing need to build roads faster and to protect the environment by recycling and reusing nonbiodegradable material such as plastic. The innovation is under development; however, it can be applied in small scale projects such as cycle paths, local roads in gated communities, or within FIFA 2022 facilities.

\subsection{App-aided maintenance - Every defect counts}

After investing billions of dollars in road construction, maintaining the road assets in good and safe condition for as long as possible becomes a challenge and a duty. Record shows that poor maintenance and late reaction to early road defects can shorten service life significantly. A tiny pothole today can be the reason for a major road undermining in a year or less. Depending on traditional routine inspections or seasonal maintenance campaigns have proven deficient. As motorists can confirm, there are numerous cases or road defects, that go unnoticed by authorities for prolonged times leading to major deterioration and the need for costly road reinstatement works along with the associated road closures and disruption to the public. Moreover, the absence of a quick response by road authorities to road defects or even road furniture damages or dislocation can have serious safety consequences and loss of property and human lives.

In recent years, and taking advantage of the current internet based communication revolution, several road authorities around the world started to turn to deploying 'appaided road maintenance' (all rights reserved as this term is created by the primary author of this paper). The idea is to deploy a mobile application as shown in Figure 5, to be used by the public and reported to road authorities' maintenance teams for review and action. The reporter using their smartphone will identify the defect, take a photo of it, drop GPS pin location, add a brief message, and click send to share the defect report which will be timed and dated automatically. The road maintenance command center will then receive the report in real time, review it, sort it by nature and urgency, add directions as necessary, add time to complete the repair, and forward the report to the engineering teams for action, as shown in Figure 6. The defect can be a pothole, a broken speed hump, a damaged road sign, cracking pavements, excessive road settlement, or similar road defects. 

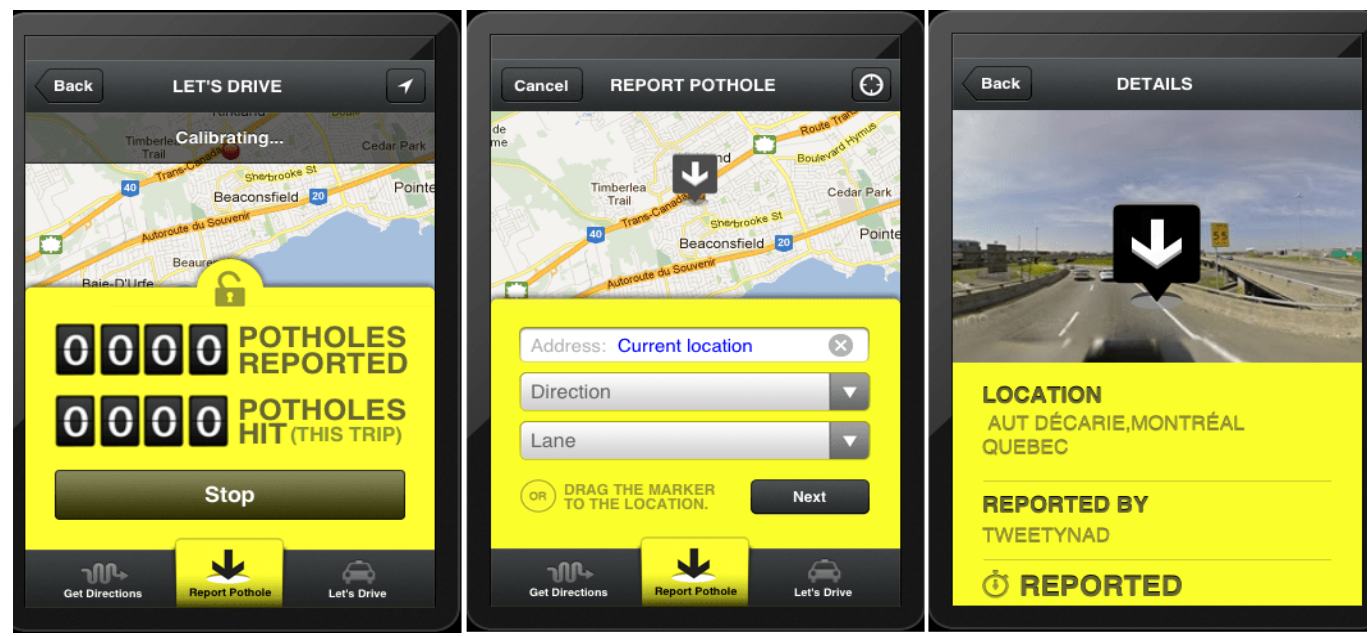

Figure 5: Instant notification app-aided road maintenance technology

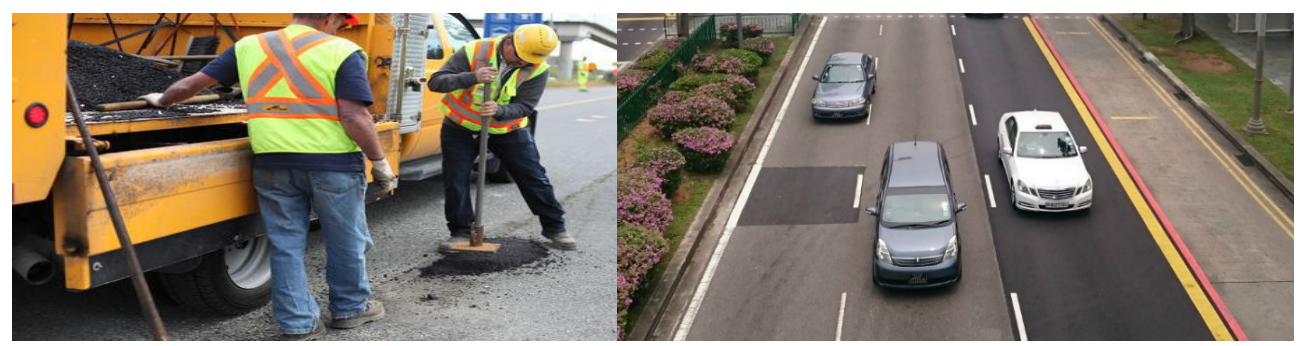

Figure 6: Prompt road maintenance on site

In cities such as Singapore, the road transportation authority promises a repair within 48 hours. Singapore is consistently on the top of the list of countries in terms of the road quality as per world ranking published by the World Economic Forum.

Conclusion: Taking good care of public assets so they last longer in a safer and tactful condition is a primary goal for road authorities. Using app-aided technology to achieve this goal is a well-developed concept that is ready for application in the State of Qatar immediately.

\section{CONCLUSION}

The road industry is moving in the right direction towards advancing pavement design, construction, and maintenance technologies. The innovative technologies presented in this paper are applicable to the State of Qatar and the region; however, such young technologies are still subject to various degrees of research and development. It would be fair to state that status of technological readiness of the innovative concepts presented in this paper would be as shown in Table 3: 
Table 3: Innovative concept readiness for application

\begin{tabular}{|l|l|l|l|}
\hline Innovation & $\begin{array}{l}\text { Testing or Demo Purposes, } \\
\text { e.g. in facilities of FIFA } \\
2022\end{array}$ & $\begin{array}{l}\text { Small Scale } \\
\text { Application }\end{array}$ & $\begin{array}{l}\text { Large Scale } \\
\text { Application }\end{array}$ \\
\hline Solar Roadways & Immediately & 5 years + & 10 years + \\
\hline Plastic Roadways & Immediately & 10 years + & 15 years + \\
\hline App-Aided Maintenance & Immediately & Immediately & 5 years + \\
\hline
\end{tabular}

Innovation is necessary for businesses and economies to progress and flourish. Indeed, innovation is a human obligation for inhabitants of the Earth. The land transportation sector, generally expressed in terms of roadways of different functions and sizes, seems to require a major innovation push that is supported by top-level leadership. Technology is available; it just needs to be used.

\section{REFERENCES}

Benedetti, B. (2012). Pothole season...There's an app for that. Home Technology Montreal, Montreal.

Brusaw, S. \& Brusaw, J. Welcome to Solar Roadways, Solar Roadways Website, Idaho.

Fourtane, S. (2019). Smart Cities: From Plastic Pollution to Plastic Roads. Interesting Engineering Website.

Greematch.co.uk (2019). How efficient are solar panels? (Greenmatch.co.uk, London).

Hashem, S. (2014). The Power of Design-Build: A Guide to Effective Design-Build Project Delivery Using the SAFEDB-Methodology. Business Expert Press, New York.

Marsh, J. (2019). Solar roadways: what you need to know, EnergySage Website.

Pasley, J. (2019). The World's First Solar Road Has Officially Crumbled into a Total Failure, Business Insider Website.

PlasticRoad (2019). Construction of 2nd PlasticRoad bicycle path in Overijssel starts, PlasticRoad Website.

Rao, G. \& Al-Kuwari, May Mohd Saeed Al-Alshaikh (2013). Assessment of Solar and Wind Energy Potential in Qatar, Qatar Petroleum, Doha, 10/27.

Robertbooker (2018). How much electricity does an average home need? Upstart Power Inc., Massachusetts.

Wavin (2018). Netherlands builds the first PlasticRoad. Wavin Website. 